\title{
Conservation and conflict: the intensification of property rights disputes under market-based conservation in Chiapas, México
}

\author{
Kate Ervine ${ }^{1}$ \\ Trent University, Canada
}

\section{Introduction}

In 2001 the Global Environment Facility's Mexico-Mesoamerican Biological Corridor project was introduced in the Mexican state of Chiapas, with a proposed duration of eight years. The Corridor is an Integrated Conservation and Development Project, intended to connect protected areas rich in biodiversity throughout the region through a series of 'corridors' in which land use and production systems are reoriented in line with 'sustainable use' criteria. The ecological logic underpinning the project was that by connecting otherwise disparate islands of biodiversity through biological corridors that restrict land use options, wildlife species connectivity and range would be enhanced, improving their odds of survival.

The Corridor itself is representative of broader shifts underway within conservation practice worldwide, that are marked by its increasing neoliberalization whereby the value of biodiversity is interpreted through a narrow market logic (Igoe and Brockington 2007; Brockington, Duffy, and Igoe 2008). Proponents of market-led conservation contend that the monetary valuation of endangered species and resources offers a 'win-win' strategy. It provides resource users with the incentive to protect and profit from that which ex ante lacked value, and also generates a development dividend where any profits earned are reinvested into local community-based projects. In this way, one of the Corridor's fundamental pillars at the local level was to support the development of market-based, biodiversity-friendly projects (i.e., organic coffee production, ecotourism, and sustainable forestry), which would, theoretically, fuel economic growth in regions marked by extreme poverty and social exclusion. I have called this approach the universal blueprint, an approach that universalizes explanations of the causes of biodiversity loss worldwide irrespective of historically and spatially-contingent factors. As applied by the Global Environment Facility, it suggests the universal applicability of a neoliberal, market-driven solution to biodiversity loss.

This paper contends that the ahistoricism of the blueprint renders it unwilling to engage with circumstances that complicate its a priori assumptions. In the case of the Corridor, and in particular its implementation in Chiapas' Lacandón Jungle, this unwillingness led to an initial disavowal of the region's long-standing, complicated, and often violent conflict over land. This produced at least two interrelated outcomes. Firstly, specific actors within participant communities were able to re-signify the meaning and purpose of the Corridor, requiring that the project be used primarily to resolve their claims to contested parcels of land. This led to significant delays; and by late 2006 no 'sustainable use' projects had been completed in the Lacandón Jungle. Second, the resolution of contested land claims took on a new sense of urgency. Importantly, market-based sustainable use projects require some form of clear property rights over the resources to be commodified and sold in the market. Where ownership is contested, as is the case in the Lacandón Jungle, the introduction of a market-based project signals to local participants the need to secure control over contested resources and lands in order to access the anticipated benefits stream that would emerge as a result of these new markets. This process can be likened to a grassroots enclosure movement that precedes the introduction of formal market-based mechanisms for resource valuation and commodification.

In this sense, I argue that while certain local actors were able to manipulate the Corridor project to meet their own ends, their actions should not be divorced from the overarching logic of neoliberal conservation which depends - indeed requires - clear property rights prior to the inception of sustainable use projects. This paper begins with a theoretical overview of market-based conservation, exploring the links between privatization and property rights. It then provides an overview of the Global Environment Facility's universal blueprint; concluding with an empirical analysis of the Corridor's trajectory in relation to the evolving conflict over land in Chiapas' Lacandón Jungle during the first five years of the project.

\footnotetext{
${ }^{1}$ Assistant Professor, Department of Political Studies, Trent University, Canada. Email: Kateervine "at" trentu.ca. This work was carried out with the financial support of a Canada Corps University Partnership Program - Canadian International Development Agency Internship on Environmental Governance, and with the aid of a grant from the IDRC, Ottawa, Canada (www.idrc.ca). Many thanks go to those individuals and organizations in Chiapas that opened their doors and shared their experiences. Thanks also to Gavin Fridell and three anonymous reviewers for their insightful feedback. All errors and shortcomings remain the author's.
} 


\section{Market-based conservation: privatization, commodification, and conflict}

Privatization is a theme that has received increasing attention within critically-oriented academic circles, particularly following the advent of neoliberal forms of governance and regulation in the 1980s, and the waves of privatization that accompanied them. At its most basic level, neoliberal market-based conservation, often expressed in the body of the Integrated Conservation and Development Project (ICDP), assumes that through the monetary valuation of biodiversity, markets will emerge within which willing buyers and sellers can exchange it, or the goods and services related to it. ${ }^{2}$ This process can include the valuation of specific territories within which ecotourism is intended, with tourist revenue dependent upon maintaining the long-term ecological integrity of the region; or it might entail payments for environmental services whereby local resource users receive financial compensation for undertaking reforestation projects, or maintaining the existing forest. In theory, it is the recognition of biodiversity's monetary value that compels conservation and development, since individuals can only profit from that which exists, allowing them, in turn, to sell these goods and services for profits to be reinvested locally. Neoliberal conservation relies on a narrow and economistic reading of human motivation whereby biodiversity's non-monetized use values - instrumental, spiritual, aesthetic, and so forth - are deemed insufficient to preserve it. Only through the monetary valuation of biodiversity, it is argued, will local resource users develop the incentive to protect and sustain it (McAfee 1999; Smith and Martin 2000; MacDonald 2005; Büscher and Whande 2007). The returns on this strategy are doubly attractive, fulfilling the neoliberal policy demands emerging from international institutions, but simultaneously offering new accumulation opportunities for individuals and firms in the face of diminishing global investment options and an international economic crisis (Smith and Martin 2000; Harvey 2003; Ervine 2007).

In order to transition biodiversity to the commodity form so that it can be bought and sold, its privatization is the necessary first step in this process. As an instance of privatization, biodiversity's commodification nevertheless permits diverse forms of property ownership (i.e., common property, private, etc.), allowing for the introduction of markets in more politically palatable ways. Privatization consists of the transfer of a specific good, resource, or entity from the public to the private realm of "control and/or ownership" (Mansfield 2007: 393). It is this transfer that has historically produced episodes of violent upheaval in societies worldwide, since privatization entails enclosing common goods and resources upon which many depend for their survival (McCarthy and Prudham 2004: 277). Biodiversity conservation falls within this category. At the heart of debates over its privatization, and thus market-led conservation, is the contention that biodiversity is part of the global commons, and ought to remain so given its central role in sustaining critical ecosystemic processes upon which the natural world and humanity depends, and given the material, social, and cultural centrality of biodiversity to the lives of indigenous populations and the poor worldwide, free of charge (O'Neill 2001: 700; Coombe 2005).

As De Angelis observes, enclosure ultimately functions to separate "people from whatever access to social wealth they may have which is not mediated by competitive markets and money as capital" (De Angelis 2004: 75). In other words, the partial or complete privatization of biodiversity as a central requisite of neoliberal conservation threatens to restrict and/or eliminate access to it, threatening, in turn, livelihood strategies and options. Concomitantly, it is this separation that transforms resource users into wage labourers. The possibility of a newly dispossessed workforce obtaining meaningful employment, compensating for that which has been lost, is often remote (Mansfield 2007:396). In this way, enclosure can engender conflict as local resource users struggle to maintain access to those resources required for their survival (Goldman 1998; Shiva 2005; Spronk and Webber 2007).

Such conflicts are, necessarily, mediated according to local social and power relations. Property rights represent a significant variable in mediating the evolution of enclosure-induced conflict, particularly within the context of a neoliberal ICDP, because it requires the existence of clear property rights prior to project inception - to whom should the development dividend go if ownership is contested? In this way, and by promising development via the commodification of biodiversity, the neoliberal ICDP has the capacity to spark a process of grassroots enclosure. This is because ownership must pre-date the project's arrival, after which the rules regarding resource use will be reformulated, in theory to the advantage of those already in possession of the land and resources in question. Consequently, stakeholders unable to demonstrate ownership rights might be excluded from sharing in project benefits (i.e., the development dividend), while access to biodiversity's goods and services is progressively restricted and/or eliminated altogether (MacDonald 2005; Corbera, Brown, and Adger 2007; Corbera, Kosoy, and Martínez Tuna 2007). This exclusion is compounded in countries like México by strict government austerity which has led to a significant withdrawal of state support to the rural sector since the 1980s, resulting in dramatically

\footnotetext{
${ }^{2}$ The neoliberal ICDP is but one variant of the ICDP model. Initially developed in the 1980s to address conservation's legacy of "parks not people" and the devastating impact that model had on local resource users, the ICDP's uptake in mainstream institutions such as the GEF has served to transform it into a tool of neoliberal efficiency (Brosius, Tsing, and Zerner 2005; Igoe and Brockington 2007).
} 
increased rural poverty and insecurity over the past few decades (Harvey 1998, 2001; Rus, Hernández Castillo, and Mattiace 2003). These overlapping forms of exclusion tend to produce destitution for some, while reconstituting development as a market good by defining its benefits as "market deliverables" in the absence of state-sponsored compensatory support.

These dangers have led some observers to argue the need to begin to incorporate land tenure and property rights issues into ICDP planning, with an eye to reducing levels of marginalization and potential conflict as a result of project interventions (Landell-Mills and Porras 2002; Duraiappah 2006; Bond et.al. 2009; Cotula and Mayers 2009). There is a need, however, for further empirical evidence documenting the relationship between the introduction of markets in biodiversity and ensuing conflicts over property rights, although the correlation between the two has been acknowledged (Millennium Ecosystem Assessment 2005: 70). Given this relationship, there is a similar need to examine how pre-existing inter-community conflicts over property-rights are redefined with the introduction of new markets for biodiversity conservation. As this article suggests, the introduction of market-based projects complicates these preexisting conflicts. In failing to theorize the competitive impulse engendered by the neoliberal ICDP, its contemporary architects further fail to understand property not as a thing, but as a social relation: the right to own it is the product of negotiation and acceptance, and where this is not possible, of violence and dispossession (O'Neill 2001; Vatn 2001: 666; Harvey 2004; Mansfield 2007: 400). Making one's survival increasingly contingent upon property ownership and the benefits to be accrued from this status serves thus as a catalyst for more, rather than less, conflict. In order to understand why this recognition remains absent in formal policy processes, we now turn to a consideration of the Global Environment Facility and its "Universal Blueprint", to better explain the political economy of power within which contemporary conservation policy is elaborated.

\section{The Global Environment Facility and its Universal Blueprint}

During the 1992 UN Conference on Environment and Development, the Global Environment Facility (GEF), at that time housed within the World Bank, became the financial mechanism for countries in the South and those with economies in transition to meet their commitments to various global environmental treaties, including the Convention on Biological Diversity. ${ }^{3}$ It provides grants to cover the additional or incremental costs required to transform "a project with national benefits into one with global environmental benefits" in six focal areas, including biodiversity, climate change, international waters, ozone depletion, land degradation, and persistent organic pollutants (Global Environment Facility 2007).

Western country donors provide the bulk of GEF funding in four year cycles, known as replenishments, allowing them to influence the direction of policy that became strongly aligned with neoliberal priorities (Ervine 2007). The GEF's voting structure requires a qualified majority consisting of 60 percent of all participating states, in addition to the support of the representatives that provide 60 percent of GEF funding. This structure is qualitatively different to those at the World Bank and IMF, and critics note that G7 countries maintain effective control over the GEF since decisions are actually made through consensus, with the threat of diminished donor contributions always possible (Horta, Round, and Young 2002: 9). That, combined with the disproportionate control wielded by the United States at the GEF, has led to a policy environment increasingly dominated by market fundamentalism. During negotiations for the $4^{\text {th }}$ GEF Replenishment in 2005, the United States was successful in spearheading the reform of GEF funding policy, requiring country performance indicators related to free market openness as a determinant of recipient country funding eligibility. These indicators come from the World Bank's Country Policy and Institutional Assessment (CPIA). By responding to donor demands for neoliberal responses to environmental problems that are capable of providing accumulation opportunities at the same time, the GEF has thus been progressively transformed into a "representational mechanism" whereby the political and economic interests of powerful donors, in particular the United States, take precedence over those of the environment and many Southern recipient states (Ervine 2007).

This shift is significant since the GEF is currently positioned as a key institution to manage global efforts at biodiversity conservation, and it is arguably the largest source of available funds internationally directed towards achieving this task (Smith and Martin 2000:25). This has led insiders to the GEF to assert that the environmental community perceives it to be "the only game in town when it comes to funding biodiversity conservation on the ground" (Evaluation Office - GEF 2004: 23). By 2009 the GEF had provided $\$ 2.8$ billion in the form of direct grants to 790 biodiversity projects in 155 countries, leveraging an additional \$7.6 billion in co-financing for the same projects (Global Environment Facility 2009). The

\footnotetext{
${ }^{3}$ While the GEF was officially separated from the World Bank during its restructuring in 1994, observers note that the Bank continues to exercise a significant degree of power over the institution, administering the GEF Trust Fund and serving as the Implementing Agency for approximately 70 per cent of GEF resources (Streck 2001: 74; Young 2002; Clémençon 2006: 52).
} 
GEF's dominance is bringing with it a progressive narrowing of conservation options in line with those preferred by the institution.

I refer to this approach as the GEF's universal blueprint. The GEF articulated its blueprint most succinctly in its report Achieving sustainability of biodiversity conservation: report of a GEF Thematic Review (World Bank 2000). The authors assert that the failure to value global biodiversity monetarily, irrespective of historically and spatially determined factors, is a great failure. This stems in large part, they argue, from a failure to understand the value and benefits of biodiversity, leading to policies and practices that undervalue it, including poorly defined and/or insecure property rights, underdeveloped or non-existent markets backed by the rule of law, and so forth (Smith and Martin 2000:11). In response, they recommend exploring a set of "innovative financial arrangements" aimed at appropriate valuation in order to achieve conservation and development ends. These include the creation of eco-markets and a corresponding system of payments for environmental services (PES); the elaboration of sustainable use projects to permit the commercialization of local goods produced in environmentally sustainable ways (coffee, honey, etc.); the expansion of bioprospecting and ecotourism initiatives; the development of private sector partnerships to advance eco-enterprises and venture capital funds; and the creation of environmental trust funds to leverage funds through market investment, private contributions, and locally generated revenues (Smith and Martin 2000:22). This policy package was reiterated in the GEF's Biodiversity Operational Strategy for GEF4 (2007-2010), with particular emphasis placed on the strengthening of a system for PES, and the use of supply chain initiatives including voluntary certification systems that "provide market-based solutions to the undersupply of social and environmental goods and services by enabling consumers to pay producers to deliver them" (Global Environment Facility 2007: 9). Within this framework, the role of government is restricted to fostering the conditions under which the market for biodiversity operates, ensuring security and predictability.

I have critiqued the GEF's universal blueprint elsewhere (Ervine 2007, 2010). Most importantly, having predetermined the causes of and solution to global biodiversity loss, the blueprint constitutes an exclusionary moment in the process of policy elaboration, whereby the necessity to confront the historically-determined and context-specific causes of biodiversity loss from one region to the next is rendered inconsequential. In Chiapas, for example, the historical concentration of land, wealth, and political power in the hands of a small ruling elite transformed the state into one of the most profitable agro-exporting states in all of México, while stripping the state's poor and indigenous populations of their lands and liberties (Rus, Hernández Castillo, and Mattiace 2003). This unequal distribution of power permitted an elite monopoly over agriculture and extractive industries throughout the $19^{\text {th }}$ and $20^{\text {th }}$ centuries, including logging, cattle-ranching, and increasingly, oil extraction. In the Lacandón Jungle, the government promoted the settlement of landless peasants, thus diffusing unrest (O'Brien 1998; De Vos 2002). A serious program of redistribution and land reform was not carried out. Extreme poverty was significantly worsened when in 1982 the Mexican state experienced a devastating economic crisis. It abandoned state support to the rural sector as part of neoliberal restructuring, with assistance to rural peasants sinking to historic lows (Collier 1994; Harvey 1998). With the inception of NAFTA trade agreements and their progressive elimination of agricultural tariffs, a full-blown economic and ecological crisis emerged as peasants, unable to compete with agricultural imports from the United States, cleared ever-increasing tracts of land while also migrating into areas rich in biodiversity (Nadal 2000). It is this history that has been occluded by the GEF's universal blueprint and specifically its efforts to create the Mexico-Mesoamerican Biological Corridor. This history is rooted in the very market forces the GEF proposes as a corrective to reverse environmental degradation. Denial, however, is not erasure, and in the case of the GEF's Corridor in Chiapas, there were significant obstacles to the project's implementation. These included the state's historic conflict over land.

\section{Implementing the MMBC in the Lacandón Jungle: property and conflict}

The GEF's Mexico-Mesoamerican Biological Corridor is an ICDP that began in 2001, linking protected areas in the four participant states - Chiapas, Quintana Roo, Yucatán, and Campeche - through a series of biological corridors. These corridors, subject to restricted use regimes in accordance with sustainability criteria, are intended to connect 'islands' of biodiversity contained within protected areas, while promoting sustainable forms of production deemed compatible with conservation goals (Kaiser 2001: 2197; Miller, Chang, and Johnson 2001: 7). The MMBC includes two biological corridors in the state of Chiapas - Selva Maya-Zoque and Sierra Madre del Sur - containing eight "focal areas" set aside to host sustainable use projects, i.e., ecotourism, organic agricultural production, sustainable logging, etc., with the expectation that project benefits would 'spill over' into the corridors' transition areas (World Bank 2000: 6; Figure 1). Having agreed to participate in the project, community representatives had to draft 'sustainable use' project proposals that would then be eligible for Corridor finance and marketing support, thereby initiating the process of commodification through which profits would, theoretically, return to these 
communities for development purposes. The MMBC is implemented by the World Bank at the country level.

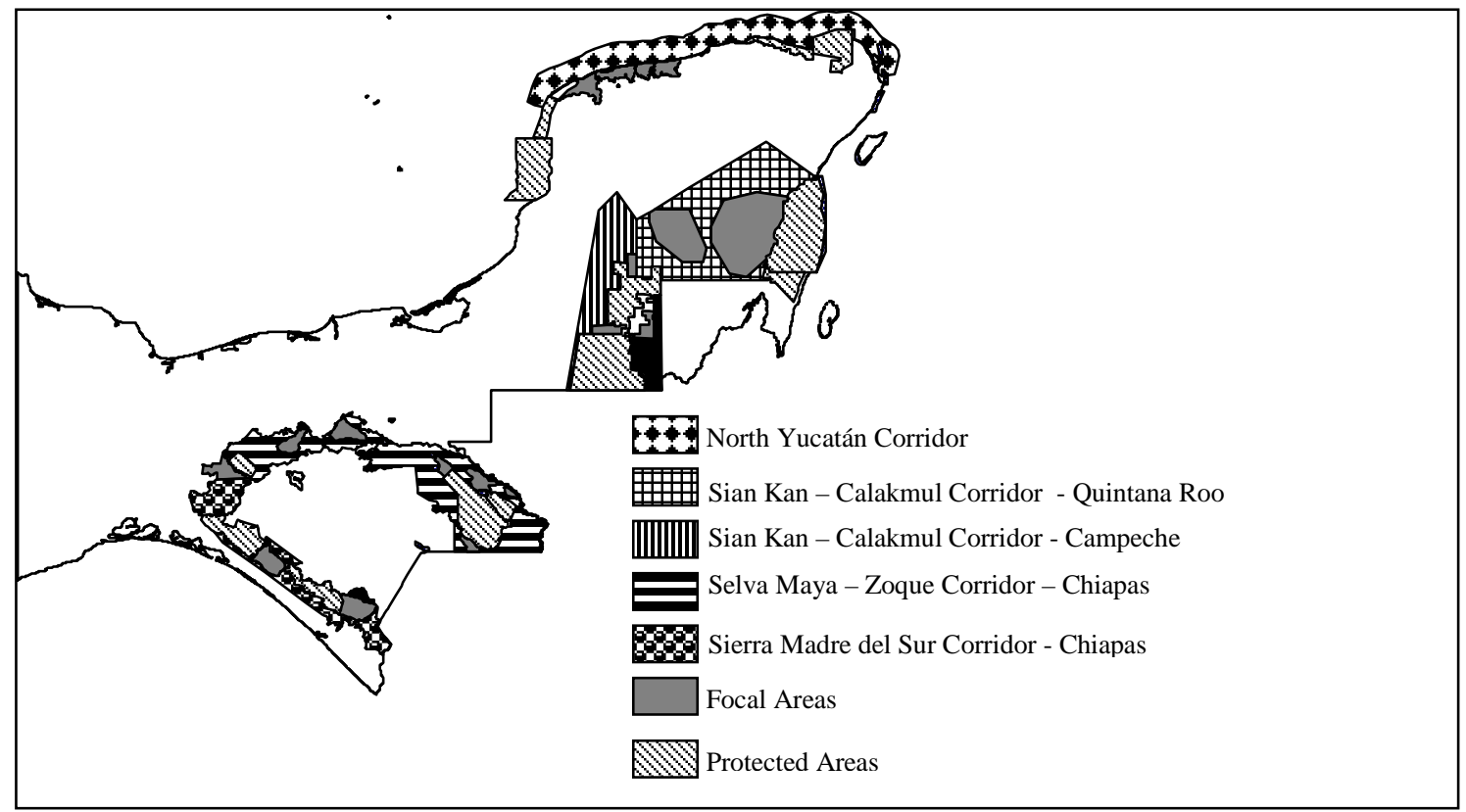

Fig. 1: Biological Corridors in southern México. Chiapas is ringed by Corridors, to the left. Redrawn from Bocanegra Aguillar (2007: 63).

Chiapas' Selva Maya Zoque Corridor (Figure 1) is situated in the heart of the Lacandón Jungle, México's largest remaining tropical rainforest, estimated to contain roughly 25 percent of the country's species diversity, "including at least 112 species of non-marine mammals, 345 species of birds, 800 species of butterflies, and 4,000 species of vascular plants" (O'Brien 1998:6). The environmental NGO Conservation International classifies the region as part of its Mesoamerican Biodiversity Hotspot, a designation reserved for regions that it estimates to "contain at least 1,500 species of vascular plants as endemics, and [that] have lost at least 70 percent of [their] original habitat" (Conservation International 2007).

Research for this work was carried over eight months in 2005 and 2006 in the Lacandón Jungle's La Cojolita Focal Area (Figure 2). While the MMBC was to last eight years (2001-2008), by the end of 2006 there were no 'sustainable use' projects in this region, with no community-led proposals completed. To understand this significant delay, one must first begin with a consideration of the region's agrarian conflict. Historically rooted and often violent competing land claims complicated the Corridor's progression, even when the stakes were high to implement it. While in the mid 2000s some observers were predicting the MMBC would be cancelled by the Bank and GEF (Villagran 2006), a request by Mexican project officials to extend the project was ultimately granted by the Bank. ${ }^{4}$ With this in mind, this work does not attempt to ascertain the overall legacy of the Corridor's sustainable use projects which remains to be determined, but to focus instead on the lessons we might learn from Chiapas' historic conflict over land in the context of market-based conservation.

\section{The roots of conflict: the struggle for land in the Lacandón Jungle}

The history of land ownership and reform in the state of Chiapas (Figure 2) has been marked by the extreme concentration of land in the hands of a small propertied class that has simultaneously controlled the levers of political power in the state. While some land reform did take place in the state following the Mexican Revolution (1910-1917), it failed to significantly challenge the structure of latifundismo characteristic of the countryside, with redistributed land often being of poorer quality and in

${ }^{4}$ This paper provides a snapshot of the Corridor's implementation until late 2006. It is thus unable to ascertain the Corridor's final legacy in terms of sustainable use projects since none were yet underway 

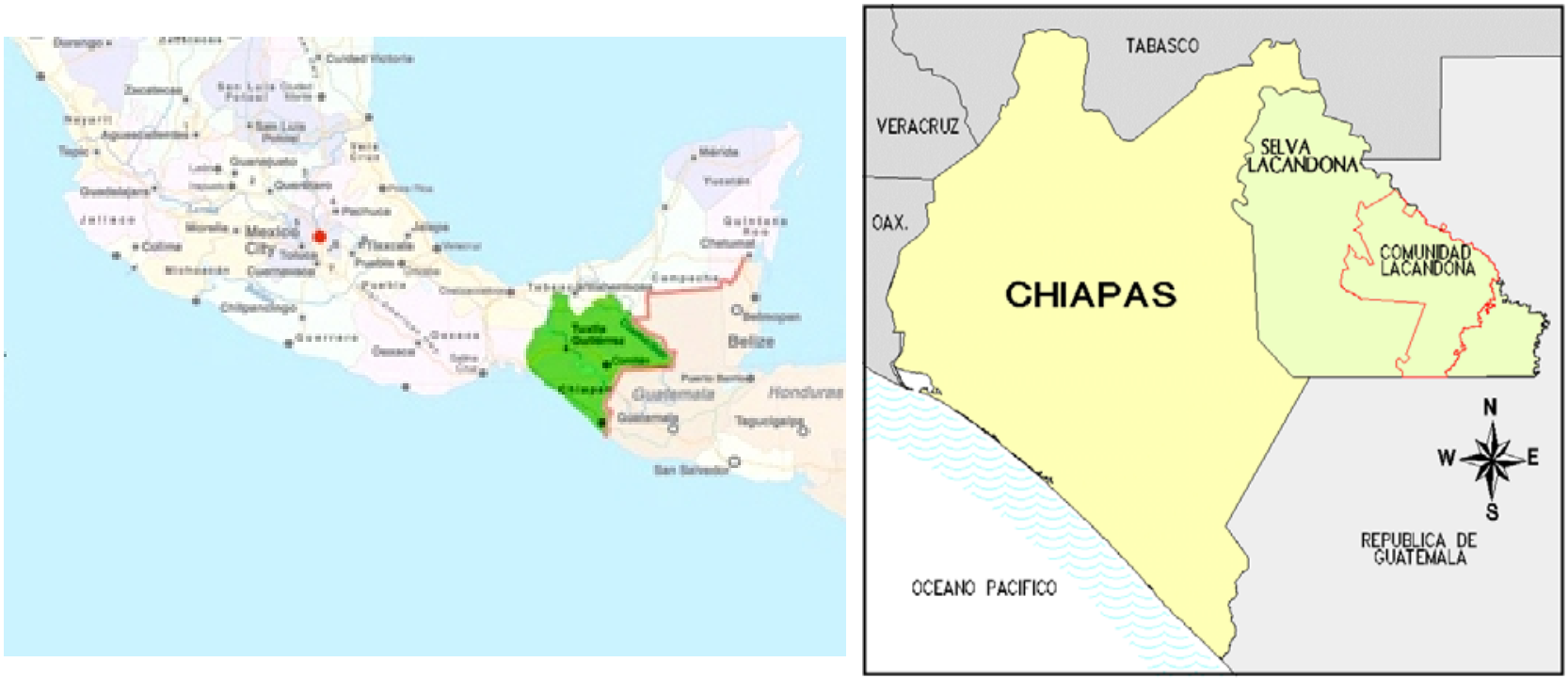

Fig 2: State of Chiapas, and the Chiapas' Selva Lacandona and Lacandón Community. Source: Wikipedia Commons, and Trench (2002:27).

environmentally marginal locations. Nevertheless, the pressure for land reform was intense, particularly following the Presidency of Lázaro Cárdenas (1934-1940), with the government embarking on a "contradictory" land distribution plan that allowed large estates to remain intact by instead distributing land within publicly-owned national territories or land that had been previously unsettled (De Vos 2002; O'Brien 1998:112). The Lacandón Jungle was one of the new frontiers for colonization in the state's land distribution strategy, serving as a conduit through which political instability could be channeled while ensuring the system's continued stability (O’Brien 1998).

Between 1940 and 1984 the state distributed a total of 1,752,900 hectares in the Lacandón Jungle, which includes the Municipalities of Altamirano, Las Margaaritas and Ocosingo. Land grants took the form of New Population Centres (Nuevos Centros de Población, NCPE), ejidos, communal property (bienes comunales), and enlargement of existing ejidos. Overall, the colonization of the Lacandón Jungle was the result of a focused government program that attempted to placate powerful interests by channeling the landless or the land-poor into the uninhabited regions of the forest. Even when colonization was spontaneous, which accounted for a significant amount of the land settled in the jungle from the 1960s onward, it was the government's refusal to redress the vast inequalities in access to land and the formal economy that left many peasants with few options but to migrate into the forest. As the 1960s wore on, however, the government's own economic interests in the region, when measured against the massive influx of migrants, led to a specific piece of legislation as the state sought to protect its growing interests in timber extraction in particular, but also in hydroelectricity, oil, and tourism development (Burguete Cal y Mayor 1980; Leyva Solano and Franco 1996; De Vos 2002; Trench 2002: 76).

On November 26, 1971, President Luis Echeverría (1970-1976) signed a Presidential Decree granting 614,321 hectares of land in the Lacandón Jungle to 66 heads of households, who officially became know as the Lacandón Community (Diario Oficial de la Federación 1972). These 66 families, or about 350-400 people, belonged to the Lacandón indigenous group which had been living in dispersed settlements in the jungle for hundreds of years. This land grant was considered "extraordinary" for three reasons. There was an unprecedented amount of land granted, transforming 66 families into the largest landowners in the state. The area was between one-third and one-half of the Lacandón Jungle's entire territory; and it dispossessed legal landowners, or those awaiting legal recognition as part of the government's resettlement program, making them illegal invaders overnight (Leyva Solano and Franco 1996; De Vos 2002; Trench 2002; Paladino 2005: 113-114).

The government justified its decision by cultivating a rationale that would suggest its primary concern was the cultural survival of the Lacandón peoples (Diario Oficial de la Federación 1972: 10; Paladino 2005: 113). Researchers, however, have pointed instead to the government's growing interest in timber extraction, which was threatened by the rapid colonization of the Jungle (De Vos 2002:113; Burguete Cal y Mayor 2006). As James Nations, an anthropologist with years of experience working in the 
Lacandón Jungle put it, "it seems likely that the government officials were more eager to deal with 350 illiterate Lacandóns than with 50,000 Tzeltal and Chol immigrants" (Nations, quoted. in Trench 2002:80).

The Lacandóns entered into an agreement with the state-owned timber company (Compañia Forestal de La Lacandona, S.A., COFOLASA) on November 27, 1974, whereby the company was given rights to exploit 35,000 cubic metres of precious timber for 25 years within the Zona Lacandona, with royalties going to the Lacandón Community (Trench 2002:90; O'Brien 1998:77-78).

One of the gravest consequences of the 1971 Presidential decree was the emergence of the region's agrarian conflict. Pre-existing settlements, many located there as a result of the government's colonization policy, were dispossessed of their lands, or the ability to gain legal title to those lands despite having begun an official process. The differing tenure status held across the Jungle meant that there was no uniform response to the creation of the Lacandón Community (Paladino 2005:126-127; De Vos 2002:116-117). De Vos (2002:115) provides figures suggesting that, in total, 38 settlements with 2,400 families were affected by the Decree, of which 17 already possessed legal title to their lands as ejidos or ampliaciones which extended existing ejidos. Those 21 settlements that lacked legal title to their lands, whether or not they had petitions in process, ultimately opted for government relocation. But many more refused, distrusting government promises of resettlement, and believing their legal status would prevail in their fight (De Vos 2002). Soon joined by other settlements fighting for legal recognition, the initial campaigners faced intense insecurity, especially because without legal title they were ineligible to receive government loans, technical assistance, production credits, and various other services (Paladino 2005:136). Some joined the Union of Ejidos Quiptic ta Lecubtesel (created in 1975) to assist them in defending their rights, while others explored alternative resistance strategies including armed resistance, with the formation of the Zapatista Army for National Liberation (Ejército Zapatista de Liberación Nacional, EZLN) in many ways a response to the injustices that households in these settlements were experiencing (O'Brien 1998:133).

The 21 communities that opted for resettlement were relocated in the new communities of Frontera Echeverría (popularly known as Frontera Corozal) and Velasco Suárez (popularly known as Nueva Palestina), and incorporated into the Lacandón Community which was largely settled in Lacanjá Chansayab, and given full communal rights in line with those accorded to the Lacandóns in 1971 (Diario Oficial de la Federación 1979). Ironically, once those settled became comuneros with the new agreement, which came into force with a Presidential Decree in 1978, they were immediately placed in a defensive stance against those settlements still classified as illegal "invaders", with the Decree defining the comuneros as "vigilantes" (guards) responsible for preventing "further 'spontaneous' immigration to the region and thus further damage to the forest" (Trench 2002:85). This has led to periodic episodes of violent confrontation as comuneros clashed with irregular settlements, many themselves victims of the government's stunning disregard for their rights to land, as the newest comuneros themselves once were. With a government unwilling to appropriately rectify the consequences of its decision, and in many instances encouraging conflict between comuneros and irregular settlements given the refusal of these settlements to incorporate into the government's official party machine, comuneros often took matters into their own hands in an attempt to secure the land they had been decreed (Díaz Solís 2005).

Conflicts over land have been further exacerbated by the creation of protected areas in the Lacandón Jungle. On January 12, 1978, the 331,200 hectare Montes Azules Biosphere Reserve was created by Presidential Decree, without any consultation with those settlements to be affected (O'Brien 1998:158). Of its total area, approximately 270,000 hectares were within the territory belonging to the Lacandón Community, leaving 61,200 hectares within which pre-existing communities were, once again, identified as "invaders" (Trench 2002:94). Between 1992 and 1998, the government created another six protected areas (PA) in the Lacandón Jungle. They included: the Lacantún Biosphere Reserve with 61,673 hectares; the Chank'in PA with 12,184 hectares; the Yaxchilán Natural Monument with 2,621 hectares; the Bonampak Natural Monument with 4,357 hectares; the Nahá PA with 3,847 hectares; and the Metsabok PA with 3,368 hectares. Combined with the Montes Azules reserve, the total protected area is 419,450 hectares. In 1993 the Lacandón Community created their own Communal Reserve, Sierra Cojolita, with 35,410 hectares. With all of these PAs falling within the Lacandón Community's territory, excluding a portion of Montes Azules, a full 87 percent of their lands are now protected. ${ }^{5}$ This is significant since PAs are subject to landuse restrictions, meaning that the Lacandón Community has progressively lost full rights to use and control their territory independently at a time when its population, and thus the need for additional land, will

\footnotetext{
${ }^{5}$ The Lacandón Jungle contains approximately 1.5 million hectares of land, leaving a significant portion of the region’s area unprotected, even while the majority of the Lacandón Community's land now falls within protected areas. According to Corridor documents, conservation benefits achieved within focal areas were expected to spill over into regions outside of chosen focal areas (WWF 2011; Smith and Martin 2000).
} 
continue to increase (Trench 2002:94). ${ }^{6}$ The result has been an increasingly combative attitude on the part of the Lacandón Community towards irregular settlement.

Government policy did shift over time. It conceded some rights to a few of the irregular settlements that had been affected by the original 1971 Decree, and in 1984-1985 it relocated and gave legal title to 259 families in an area known as El Desempeño located in the northeastern corner of the Community's territory. Again in 198926 settlements were legalized by President Carlos Salinas de Gortari (1988-1994) (Paladino 2005:179; Díaz Solís, Interview, 2005). Combined, these decisions led to the reduction of the Community's territory by some 113,000 hectares, fuelling increased insecurity and a local commitment to defend Lacandón Community land. For example, between 1988 and 1994, the comuneros from Nueva Palestina increased the amount of land they were actively working from 1,237.5 hectares to 29,791.5 hectares, in an effort, states Paladino, to "assure present and future claims to land" (Paladino 2005:181).

The sources of conflict in the Lacandón Jungle are complex. They include the irregular settlements contesting the legitimacy of the Lacandón Community's original land claims stemming from the 1971 decree. This contest inspired in part the formation of the Zapatista movement, its 1994 uprising, and its continued resistance. In addition, the Community itself defended its right to territory against "invaders" and the state and international actors involved in gazetting land for conservation. The broader context is the rural sector's neoliberalization, which has intensified the pressure to expand agricultural production into unoccupied lands, and the poor and landless populations' efforts to colonize the forest (Nadal 2000). It is upon this pre-existing conflict over land that the MMBC was superimposed, bringing with it a marketbased agenda which demanded clear and unequivocal property rights. Land conflict, which took a deadly turn in November 2006, emerged as the central variable shaping the MMBC's implementation in the Lacandón Jungle. In such cases, conflicts over tenure, already intense, develop a new sense of urgency. The MMBC became enmeshed in an existing property dispute.

\section{The agrarian conflict and the MMBC}

The MMBC's La Cojolita Focal Area is made up of the Lacandón Community, which includes the communities of Frontera Corozal, Nueva Palestina, and Lacanjá Chansayab. As noted above, the Community's relationship to conservation initiatives have been marked by intense hostility as more and more of their territory has become protected for conservation purposes. Their land use options were restricted in the context of significant population growth and widespread economic crisis (Tejada Cruz 2002). The Community staunchly resisted the redesignation of their territory throughout the 1980s and 1990s (Tejada Cruz 2002; Muttoo Osborne 2011). The government's neoliberal agrarian reforms begun in the 1980s, and included the elimination of subsidies for coffee and corn production. These are both critical to peasant livelihoods. In addition Article 27 of the Mexican Constitution was reformed, and the North American Free Trade Agreement was introduced. NAFTA permitted the import of much cheaper American corn, which also affected comuneros in the Lacandón Community.

As the community leadership in Frontera Corozal noted during interviews with the author, identifying new and alternative sources of income was their key priority in this precarious economic environment.' Ironically, the leadership had begun to identify conservation as one such alternative since neoliberal conservation promised, at least in theory, that income could be derived from eco-initiatives. It was within this context that local officials identified the agrarian conflict as the key obstacle to fully participating in market-based conservation schemes such as the Corridor Without legal title to these lands and their resources, they saw little possibility of developing successful sustainable use projects under the Corridor's guidance (Alvaro Cruz 2005; Díaz Solís 2005; Gómez 2005; Ruiz Hernández 2005; Sánchez 2005).

While the Corridor was not the only market-based conservation scheme under consideration or underway in the Lacandón Jungle, ${ }^{8}$ it did come to occupy a central position in the politics of the agrarian conflict. Specifically, the Community's leadership decided to demand Corridor funds to resolve their land issues, with this funding being a prerequisite for further participation in the project. As a local biologist in Frontera Corozal explained:

\footnotetext{
${ }^{6}$ It was not until 1988 that the government executed its 1978 Decree creating Frontera Corozal and Nueva Palestina, whereby it reduced the Community's territory from 614,321 to 501,106 hectares.

${ }^{7}$ On October 8, 2005, the leadership of Frontera Corozal organized a meeting with the author to discuss the MMBC, and which included local officials and comuneros. For a detailed discussion of community-based inequalities within the Lacandón Community, especially with respect to class and gender differentials, and how this affects projects such as the Corridor, see Ervine (2010).

${ }^{8}$ For example, see Muttoo Osborne (2011) for a discussion of carbon forestry in Frontera Corozal.
}

Journal of Political Ecology $\quad$ Vol.18, 2011 
One of the most complicated problems we have here in the Lacandón Community is the agrarian problem and in order to fully resolve the problem, we have the Corridor. We are participating in order to resolve the problem, because we can't talk about conservation if we have problems with people invading our land, it would be illogical. Therefore, we want the Mesoamerican Biological Corridor to contribute to the resolution of the agrarian problem. (Gómez, Interview, 2005)

This position was shared by the Corridor's council members on the Corridor State Council in Nueva Palestina and Lacanjá Chansayab during interviews with the author. They discussed the Community's decades long battle to secure the integrity of their lands - a battle they asserted inhibited the possibility of conserving these lands and successfully participating in the Corridor (Chamboro 2005; Flores 2005).

Persistent and increasing economic insecurity in the Lacandón Community, along with their shrinking territory and a growing population, led to a specific urgency to identify alternative means of income, of which neoliberal conservation became one potential source. Until disputed land claims could be resolved, however, this strategy remained limited. Comuneros noted that this was especially the case since ecotourism was central to the community's economic plans, requiring predictability in access to the regions rich archaeological and natural sites, a number of which were situated upon or near contested localities. The same was true of sustainable forestry, which community officials also wished to pursue with Corridor funds.

When the Community submitted its first action plan to Corridor officials in 2004, instead of identifying sustainable use projects of interest, they requested 2,400,000 pesos (US\$175,000) of Corridor funds to resolve the agrarian conflict, a request eventually approved at a reduced sum of 500,000 pesos (Sánchez Jímenez 2006; Velázquez Hernández 2006). Critics charged that the Lacandón Community understood the Corridor as a means to acquire resources and that they had "adopted an extremely aggressive posture" in an effort to do so, while failing to properly understand the role of the Corridor (PADEP 2004). What these critics failed to take seriously, as suggested by a local anthropologist with years experience working in the Lacandón region, was that in doing conservation, whether market-based or not, land is the central issue. Marketizing conservation simply adds a new layer of complexity given the potential economic gains it offers insecure populations (Morris 2005).

In 2004 the project "Acompañamiento Técnico para conribuir a solucionar el problema agrario en la Cojolita de la zona Lacandona" (Technical support to contribute to the solution of the agrarian problem in La Cojolita of the zona Lacandona) was approved by Corridor officials. Project documents stated that the project "would not look to resolve the problem, but rather to contribute to a solution" (PADEP 2004, emphasis added). This was to be done by providing technical assistance in the form of conflict resolution, mediation, dialogue, and workshops, along with support in the negotiation of agreements between the stakeholders. The work was carried out by consultants contracted through the Corridor.

Negotiations thus began, with Corridor support, between the Lacandón Community and 28 communities known as the El Desempeño group. These 28 had been classified as "invaders" by the Lacandóns, who sought their immediate relocation. Their tenure status varied. There were those that possessed legal title to their land prior to the transfer of 501,106 hectares to the Zona Lacandona in 1988 recall that in 1984 and 1985 the government had relocated and given legal tenure to 259 families affected by the 1971 Decree to the Zona El Desempeño (Romaní Cortés 2007). Other irregular settlements had received subsequent resolutions, while there were those that had petitioned for their land but had not received favourable rulings. Much of this was complicated by the fact that it took the government until 1988 to officially delimit the Zona Lacandona, with much uncertainty regarding what constituted national lands versus those of the Lacandón Community. Another point of confusion is the fact that these irregular settlements, some possessing legal title predating the 1988 delimitation of the Zona Lacandona, fall within the territory controlled by the Lacandón Community (Romaní Cortés 2007). It is unclear why the government drew the boundaries of the Zona Lacandona in such a way so that these communities were included within its territory. Whatever the case, the Lacandón Community had become increasingly vocal and active in pursuing the eviction of these communities.

As part of the conflict resolution process, in 2005 the Mesa de Concertación Agraria, which was more popularly known as the Mesa de San Javier and headed by the Ministry of Agrarian Reform, was created as the main negotiating body through which an agreement between the Lacandón Community, the government, and the 28 settlements could be reached (Romaní Cortés 2007). The Desempeño group, in an effort to draw on the strength of their numbers, had agreed that they would negotiate together for a collective resolution to the problem that would ensure all were satisfied with the outcome. One of the lead negotiators on behalf of the group asserted in a 2005 interview that this meant that they were demanding a resolution for each of the 28 communities and would accept nothing less than this (Jiménez 2005). Many believed it possible that the government's historical tactics of dividing communities and then pitting them against each other would be a strategy employed in their case as well, and so they set out from the 
beginning to resist this prospect. At some point in the process, however, it appeared that this strategy fell apart.

With the Mesa de San Javier having begun formal negotiations in April of 2005, by February 22 2006 the government had passed Decrees granting land rights to 24 of the 28 settlements in El Desempeño (Flores Montejo 2008). The Lacandón Community would be paid approximately 170,000,000 pesos (US\$12.5m) in compensation for lost territory. ${ }^{9}$ However, the agreement, which had the government declaring a historic end to thirty years of conflict in the Zona Lacandona, left four communities without a resolution to their claims. They included Flor de Cacao, Ojo de Agua, San Jacinto Lacanjá and Viejo Velasco Suárez. In order for an agreement to be reached between the parties, one that would ultimately exclude these four settlements, community members from El Desempeño believe that three negotiators that had been appointed from their communities, as representatives at the Mesa de San Javier and for meetings that took place in El Limonar, accepted bribes from the government, thereby agreeing to the relocation. According to their accounts, all four communities in question possessed title to their lands as a result of the 1984 resettlement agreement that had been struck between the government, the communities, and the Lacandón Community itself; and they themselves assert that they had never agreed to government relocation (Acción Urgente 2006).

Nonetheless the agreement was arrived at. It was shortly thereafter that the four communities began to report that they were receiving threats of forced eviction and violence from the Lacandón Community and government officials, should they fail to relocate. Various human rights organizations in the state of Chiapas, including the Centro de Derechos Humanos Fray Bartolomé de las Casas, A.C., which was founded by former Catholic Bishop Samuel Ruiz, issued a number of Urgent Actions in July and August of 2006, warning the government of imminent violence against the four communities (Centro de Derechos Humanos Fray Bartolomé de las Casas 2006). Finally, on the morning of November 13, 2006, over 200 individuals entered the community of Viejo Velasco Suárez, armed with machetes, bats, and high calibre firearms. Many were identified as having come from Nueva Palestina but also as wearing state police uniforms, and in the ensuing conflict, four members of Viejo Velasco were left dead, while an additional four were reported missing. Two individuals from Nueva Palestina were also killed (Amnesty International 2006). On July 6, 2007, a human rights mission to the area discovered the personal belongings of two of the disappeared from Viejo Velasco. In all, this attempt to violently evict the community of Viejo Velasco from its land stood as a grim reminder that the agrarian conflict was nowhere near to being resolved, with or without the assistance of the Corridor's consultants.

On November 15, 2006, representatives of the Lacandón Community issued a statement contending that the behaviour of the four communities excluded from the negotiated settlement was the primary reason behind their opposition to regularizing their lands. Such behaviours, it was argued, included physical and sexual assaults against comuneros and their families; the killing of their animals; the involvement of these settlements in the trafficking of illegal Guatemalan and Honduran immigrants; armed robberies; the cultivation of marijuana; and the cutting of the forest with the intent of commercial sale. Finally, it was argued that the four settlements were using the jungle as a refuge to escape the law and that they were members of the Zapatista movement (Bienes Comunales Zona Lacandona 2006).

Evidence of such illegal activities is difficult obtain. Human rights observers and members of the four communities in question suggest instead that the government and the Lacandón Community have other interests in this region, with references to criminal activities and violence serving to occlude them. Testimonials given by members of the four communities during a human rights mission to the region in August 2006 identified the Lacandón Community's strategic economic interests in the region as a significant factor escalating the conflict. The possibility for sustainable timber exploitation in the vicinity of the four settlements remains high, while their proximity to the ancient Mayan ruins of Yaxchilán offers significant potential for ecotourism - something in which the Lacandón Community is already heavily invested (García Aguirre 2005; Global Exchange 2006). Finally, inhabitants of Viejo Velasco suggested during the August 2006 testimonials that they were a target for aggression since they constituted a civilian support base of the EZLN, belonging to the autonomous Zapatista municipality of Vicente Guerrero (Global Exchange 2006).

According to Carmelino Flores Montejo, the Corridor's lead consultant who was involved in the negotiations between the Lacandón Community and irregular settlements within its territory, as of March of 2008 the agrarian conflict had yet to be resolved in the region (Flores Montejo 2008). While the 24 communities discussed above eventually received tenure to their lands, for which the Lacandón

\footnotetext{
${ }^{9}$ More than one observer that I spoke with, including one individual working for the Ministry of Tourism in Chiapas in 2005, asserted that one of the key reasons motivating the Lacandón Community to demand the eviction of these communities, was the prospect of receiving financial compensation for these lands that they were not compensated for in 1984 (even when some had possessed legal title as a result of the 1984 agreement which was signed by a representative from the Community along with the government ) (Hernández Burguete 2005).
} 
Community was financially compensated, the other 4 cases had still not been resolved, while a further 8 outside of the Zona El Desempeño also remained without resolution. Flores Montejo, in summarizing the situation, stated that "where the level of social conflict in relation to land tenure is high, and where it is not reduced and resolved, it would be difficult to guarantee that the fragmentation of the forest will be avoided" (Flores Montejo 2008:2). Indeed, by 2008 the MMBC remained largely ineffectual in spurring meaningful conservation in the region.

\section{Conclusion}

The experience of the MMBC in Chiapas' Lacandón Jungle that has been considered in this paper provides us with a number of lessons.

Firstly, it provides a clear demonstration of the agency and power of local level actors to confront and reconfigure externally-defined projects to suit their own interests. By demanding that the Corridor be used to resolve the agrarian conflict, the Lacandón Community was able to initiate a process which concluded with a decision to award them $170,000,000$ pesos (US\$12.5m) in compensation for lands lost to 24 irregular settlements, even though their rights to these lands remained questionable. In this way, it would be a mistake to assume that top-down projects necessarily rob local actors of their agency.

Secondly, the experience of the Corridor in the Lacandón Jungle provides us with a caution in relation to the introduction of market-based conservation schemes within the context of pre-existing intercommunity conflict. Indeed, as noted above, multiple human rights missions to the four communities threatened with eviction by the Lacandón Community documented the strategic economic value of the region, especially in relation to ecotourism and sustainable logging, as a factor in the escalating conflict. Comuneros in the Lacandón Community corroborated this fact during numerous interviews with the author. While the prospect of profiting from the introduction of eco-projects does not today require the formal introduction of a project such as the Corridor, comuneros were highly cognizant of the fact that it promised to bring with it the finance and marketing support to get such projects off the ground. In this way, by requiring clear ownership rights over those resources "to be" commodified, the project itself intensified the need to "resolve" pre-existing disputes. That said, the Corridor was not the only market-based conservation initiative underway in the region, meaning that the pressure to resolve land rights conflicts in order to benefit from emerging eco-markets may well have derived from multiple sources. What the Corridor offers us, then, is a window into how this process may begin to play out as neoliberal conservation progresses.

In the end, the case of the Corridor in Chiapas suggests that market-based conservation and development may rarely be the 'win-win' solution suggested by its proponents. Rather, such strategies, by demanding the privatization and thus enclosure of biodiversity, whether partial or full, necessarily produce uneven results amongst those dependent upon biodiversity as a public good to meet their livelihood needs. It is thus that within market-based initiatives, the seeds of competition and conflict take root, or are intensified as the promises associated with new markets in biodiversity - community development, new sources of revenue, and so forth - compels communities to stake their claims to contested land and resources. Failing to take seriously these lessons not only diminishes the possibility of reversing biodiversity loss in the global South, but also threatens to marginalize further those populations most vulnerable to the insecurity of the market.

\section{Bibliography}

Acción Urgente. 2006. El gobierno no ha resuelto el conflicto agrario en la selva. Zona El Desempeño.

Alvaro Cruz, S. 2005. Interview with author. Frontera Corozal, October 21, 2005.

Amnesty International. 2006. Fear for safety/fear of ill-treatment/arbitrary detention. Amnesty International.

Bienes Comunales Zona Lacandona. 2006. Comunicado oficial. Comunidad Lacandona, November 16, 2006.

Bocanegra Aguillar, M.A. 2007. La participación social en la cooperación internacional para el desarrollo: el caso del Corredor Biológico Mesoamericano en Chiapas. Maestría. México, D.F.: Cooperacion Internacional para el Desarrollo \& Instituto Mora.

Bond, I., M. Grieg-Gran, S. Wertz-Kanounnikoff, P. Hazlewood, S. Wunder, and A. Angelsen. 2009. Incentives to sustain forest ecosystem services: A review and lessons for REDD. London: International Institute for Environment and Development. http://pubs.iied.org/pdfs/13555IIED.pdf

Brockington, D., R. Duffy, and J. Igoe. 2008. Nature unbound: conservation, capitalism and the future of protected areas. London: Earthscan.

Brosius, P., A.L. Tsing, and C. Zerner, eds. 2005. Communities and conservation: histories and politics of community-based natural resource management. Walnut Creek, CA: AltaMira Press. 
Burguete Cal y Mayor, A. 1980. La selva Lacandona: riqueza sin desarrollo. México, D.F.: Universidad Autónoma de México.

-- 2006. Interview with author. San Cristóbal de las Casas, June 20, 2006.

Büscher, B., and W. Whande. 2007. Whims of the winds of time? Emerging trends in biodiversity conservation and protected areas management. Conservation and Society 5 (1):22-43. http://tinyurl.com/3tghufp

Centro de Derechos Humanos Fray Bartolomé de las Casas, A.C. 2006. Amenazas de desalojo y hostigamiento a pueblos indígenas en la selva lacandona. San Cristóbal de las Casas: Centro de Derechos Humanos Fray Bartolomé de las Casas, A.C.

Chamboro, A. 2005. Interview with author. Lacanjá Chansayab, November 24, 2005.

Clémençon, R. 2006. What future for the Global Environment Facility? The Journal of Environment and Development 15 (1):50-74.

Collier, G. 1994. Basta! Land and the Zapatista rebellion. Oakland, California: Institute for Food and Development Policy.

Conservation International. 2007. Biodiversity hotspots: Hotspots defined. Conservation International. [accessed December 2 2007]. http://tinyurl.com/3tuxlso

Coombe, R. 2005. Protecting traditional environmental knowledge and new social movements in the americas: Intellectual property, human right, or claims to an alternative form of sustainable development? Florida Journal of International Law 17 (1):115-135.

Corbera, E., K. Brown, and N. Adger. 2007. The equity and legitimacy of markets for ecosystem services. Development and Change 38 (4):587-613.

Corbera, E., N. Kosoy, and M. Martínez Tuna. 2007. Equity implications of marketing ecosystem services in protected areas and rural communities: Cases from Meso-America. Global Environmental Change 17:365-380.

Cotula, L., and J. Mayers. 2009. Tenure in REDD: Start-point or afterthought? London: International Institute for Environment and Development. http://pubs.iied.org/pdfs/13554IIED.pdf

De Angelis, M. 2004. Separating the doing and the deed: capital and the continuous character of enclosures. Historical Materialism 12 (2):57-87.

De Vos, J. 2002. Una tierra para sembrar suenos: historia reciente de la selva Lacandona, 1950-2000. México, D.F.: Centro de Investigaciones y Estudios Superiores en Antropologia Social.

Diario Oficial de la Federación. 1972. Resolución sobre reconocimiento y titulación a favor del núcleo de población Zona Lacandona, municipio de Ocosingo, Chiapas, de una superficie de seiscientas catorce mil trescientas veintiuna hectáreas de terrenos comunales.

-- 1979. Resolución sobre reconocimiento de derechos agrarios comunales en le núcleo de población denominado "Zona Lacandona", municipio de Ocosingo, Chiapas.

Díaz Solís, P. 2005. Interview with author. Frontera Corozal, October 8, 2005.

Duraiappah, A. 2006. Markets for ecosystem services: A potential tool for multilateral environmental agreements. Winnipeg: International Institute for Sustainable Development.

Ervine, K. 2007. The greying of green governance: power politics and the Global Environment Facility. Capitalism, Nature, Socialism 18 (4):125-142.

-- 2010. Participation denied: The Global Environment Facility, its universal blueprint, and the Mexico-Mesoamerican Biological Corridor in Chiapas. Third World Quarterly 31 (3):773-790.

Evaluation Office - GEF. 2004. GEF biodiversity program study. Washington, DC: GEF.

Flores, C. 2005. Interview with author. Nueva Palestina, November 25, 2005.

Flores Montejo, C. 2008. Resumen ejecutivo de la consultoría: contribución al proceso de información y capacitación agraria en el estado de Chiapas. Comunidad Lacandona: Corredor Biológico Mesoamericano-México UTR/Chiapas.

García Aguirre, M.A. 2005. Interview with author. San Cristóbal de las Casas, September 12, 2005.

Global Environment Facility. 2007. Biodiversity focal area strategy and strategic programming for GEF-4. Washington, DC: GEF. http://tinyurl.com/3zc9yaz

-- 2008. Projects. Global Environment Facility 2007 [accessed May 12 2008]. http://www.gefweb.org/interior.aspx?id=90

-- 2009. Biodiversity fact sheet - June 2009. GEF 2009 [accessed Oct 1 2011]. http://www.thegef.org/gef/node/2830. 
Global Exchange. 2006. Harassment, threats, and illegal, forcible relocation in the Lacandon jungle: Firsthand observations of a U.S. Delegation. San Francisco: Global Exchange. http://tinyurl.com/6abyb80

Goldman, M. 1998. Introduction: The political resurgence of the commons. In M. Goldman (ed.) Privatizing nature: political struggles for the global commons. New Jersey: Rutgers University Press. pp 1-19.

Gómez, F. 2005. Interview with author. Frontera Corozal, October 21, 2005.

Harvey, D. 2003. The new imperialism. Oxford: Oxford University Press. --. 2004. The 'new' imperialism: accumulation by dispossession. In L. Panitch and C. Leys (eds.) Socialist Register 2004: The new imperial challenge. London: The Merlin Press Ltd. pp 63-87.

Harvey, N. 1998. The Chiapas rebellion: the struggle for land and democracy. London: Duke University Press. --. 2001. Globalization and resistance in post-cold war México: difference, citizenship and biodiversity conflicts in Chiapas. Third World Quarterly 22 (6):1045-1061.

Hernández Burguete, T. 2005. Interview with author. Frontera Corozal, December 10, 2005.

Horta, K., R. Round, and Z. Young. 2002. The Global Environment Facility: the first ten years - growing pains or inherent flaws? Ottawa and Washington DC: The Halifax Initiative and Environmental Defense. http://tinyurl.com/44sly67

Igoe, J., and D. Brockington. 2007. Neoliberal conservation: a brief introduction. Conservation and Society 5 (4):432-449. http://tinyurl.com/3qkgge8

Jiménez, A. 2005. Interview with author. Lacanjá Tzeltal, October 6, 2005.

Kaiser, J. 2001. Bold corridor project confronts political reality. Science 293:2196-2199.

Landell-Mills, N., and I. Porras. 2002. Silver bullet or fools' gold? A global review of markets for forest environmental services and their impact on the poor. London: International Institute for Environment and Development. http://pubs.iied.org/9066IIED.html

Leyva Solano, X., and G. Franco. 1996. Lacandonia: Al filo del agua. México, D.F.: Fondo de Cultura Económica: Centro de Investigaciones y Estudios Superiores en Antropologia Social.

MacDonald, K.I. 2005. Global hunting grounds: power, scale and ecology in the negotiation of conservation. Cultural Geographies 12(3): 259-291.

Mansfield, B. 2007. Privatization: property and the remaking of nature-society relations. Antipode 39 (3):393-405.

McAfee, K. 1999. Selling nature to save it? Biodiversity and the rise of green developmentalism. Environment and Planning D: Society and Space 17 (2):133-154.

McCarthy, J., and S. Prudham. 2004. Neoliberal nature and the nature of neoliberalism. Geoforum 35 (3):275-283.

Millennium Ecosystem Assessment. 2005. Ecosystems and human well-being: biodiversity synthesis. Millennium Ecosystem Assessment. http://www.millenniumassessment.org/en/Synthesis.html

Miller, K., E. Chang, and N. Johnson. 2001. Defining common ground for the Mesoamerican Biological Corridor. Washington DC: World Resource Institute (WRI). http://tinyurl.com/3wb62f2

Morris, C. 2005. Interview with author. San Cristóbal de las Casas, December 15, 2005.

Muttoo Osborne, T. 2011. Carbon forestry and agrarian change: access and land control in a Mexican rainforest. Journal of Peasant Studies 38 (4):859-883.

Nadal, A. 2000. The environmental and social impacts of economic liberalization on corn production in México. Oxford, UK: Oxfam GB. http://tinyurl.com/3eolpoo

O'Brien, K. 1998. Sacrificing the forest: environmental and social struggles in Chiapas. Boulder: Westview Press.

O'Neill, J. 2001. Property, care, and environment. Environment and Planning C: Government and Policy 19: 695-711.

PADEP, A.C. 2004. Evaluación tecníca del Corredor Biologíco Mesoamericano-México: reporte final. PADEP, A.C.

Paladino, S. 2005. We are the guardians of the selva: conservation, indigenous communities, and common property in the selva Lacandona, México. PhD dissertation, Anthropology. Athens, GA: University of Georgia.

Romaní Cortés, J. 2007. Contribución a la conclusión del proceso de conciliación agraria y mediación de los conflictos agrarios en la zona de "la cojolita": Resumen ejecutivo. México, D. F. 
Ruiz Hernández, A. 2005. Interview with author. Frontera Corozal, October 21, 2005.

Rus, J., R.A. Hernández Castillo, and S. Mattiace. 2003. Introduction. In J. Rus, R.A. Hernández Castillo and S. Mattiace (eds.) Mayan lives, Mayan utopias: the indigenous peoples of Chiapas and the Zapatista rebellion. New York: Rowman \& Littlefield. pp 1-26.

Sánchez, J. 2005. Interview with author. Frontera Corozal, December 7, 2005.

Sánchez Jímenez, J. 2006. Interview with author. Frontera Corozal, July 17, 2006.

Shiva, V. 2005. Earth democracy: justice, sustainability, and peace. London: Zed Books.

Smith, S., and A. Martin. 2000. Achieving sustainability of biodiversity conservation: report of a GEF thematic review. Washington, DC: GEF. http://tinyurl.com/3g6cg5d

Spronk, S., and J. Webber. 2007. Struggles against accumulation by dispossession in Bolivia: the political economy of natural resource contention. Latin American Perspectives 34 (2):31-47.

Streck, C. 2001. The global environment facility - a role model for international governance? Global Environmental Politics 1 (2):71-94.

Tejada Cruz, C. 2002. Apropiación social del territorio y política ambiental en la selva lacandona, chiapas: El caso de frontera corozal, comunidad lacandona, Ciencias en Desarrollo Rural Regional, Universidad Autónomo Chapingo, San Cristóbal de las Casas.

Trench, T. 2002. Conservation, tourism and heritage: continuing interventions in Lacanjá Chansayab, Chiapas, México. PhD disseration in Social Anthropology. Manchester, UK: University of Manchester.

Vatn, A. 2001. Environmental resources, property regimes, and efficiency. Environment and Planning C: Government and Policy 19 (5):665-680.

Velázquez Hernández, C. 2006. Interview with author. Tuxtla Gutierrez, CONABIO, June 29,2006.

Villagran, F. 2006. Personal communication. Washington, DC, December 4, 2006.

World Bank. 2000. Project appraisal document on a proposed grant from the Global Environment Facility trust fund in the amount of SDR 11.5 million to Nacional Financiera, S.N.C. for a Mesoamerican Biological Corridor Project. Washington, DC: World Bank. http://tinyurl.com/3g3yrrq

World Wide Fund for Nature (WWF) International. 2011. Mexico: the State of Chiapas. Washington, DC. www.worldwildlife.org/what/wherewework/mexico/thestateofchiapas.html

Young, Z. 2002. A new green order? The World Bank and the politics of the Global Environment Facility. London: Pluto Press. 


\begin{abstract}
This article examines the implementation of the Global Environment Facility's (GEF) MexicoMesoamerican Biological Corridor in the Lacandón Jungle of Chiapas, México. As an Integrated Conservation and Development Project, the Corridor is rooted in the GEF's "universal blueprint", a program of biodiversity marketization as a simultaneous conservation and poverty reduction strategy. It is argued that the blueprint, whose framework both assumes and demands clearly delineated property rights as the vehicle for determining payments for the preservation of ecosystem services, denied the existence of Chiapas' historic conflict over land, thereby adding a new layer to it. The increasing ubiquity of marketbased conservation strategies such as the Corridor may lead to or exacerbate conflicts over land and resources. Outcomes tend to favour more powerfully-situated local actors. Such projects, rather than solving poverty and inequality, may lead to new forms of marginalization, while undermining conservation goals.
\end{abstract}

Keywords: Global Environment Facility, Mexico-Mesoamerican Biological Corridor, market-based conservation, land tenure conflict.

\title{
Résumé
}

Cet article examine la mise en œuvre du Couloir Biologique Méso-Américain du Mexique (CBM Mexique) dans la Jungle Lacandone du Chiapas, financé par le Fonds pour l’Environnement Mondial (FEM). En tant que le CBM intégré de conservation et de développement, le couloir est enracinée dans ce que l'auteur désigne comme «modèle universel» de l'FEM - un programme de marchandisation de la biodiversité avec deux axes - conservation, et une stratégie de réduction de la pauvreté. Il est soutenu que le projet, dont le cadre à la fois suppose et exige des droits de propriété clairement définis comme le véhicule pour déterminer les paiements pour la préservation des services écosystémiques, a nié l'existence d'un conflit historique du Chiapas sur le foncier. L'omniprésence des stratégies de conservation fondées sur le marché tels que le Corridor peut entraîner ou exacerber les conflits sur les terres et les ressources naturelles. Les conflits fonciers ajoute une nouvelle couche. Les résultats tendent à favoriser les plus puissant parmi les acteurs locaux. Ces projets, plutôt que de résoudre la pauvreté et les inégalités, peut conduire à de nouvelles formes de marginalisation, tout en sapant les objectifs de conservation.

Mots clés: Fonds pour l'Environnement Mondial, couloir biologique méso-américain du Mexique, des instruments de marché, les conflits fonciers

\section{Resumen}

Este ensayo examina la implementación del Corredor Biológico Mexico-Mesoamericano (CBMM) del Fondo para el Medio Ambiente Mundial (GEF) en la Selva Lacandona de Chiapas, México. Definido como un proyecto integral de desarrollo y conservación, el Corredor se basa en loque el autor se refiere como el “diseño universal” del GEF,” es decir, un programa de mercadeo de la biodiversidad, que simultáneamente busca la conservación ambiental, a la vez que intenta reducir la pobreza. Se argumenta que el diseño -cuyo marco asume y exige derechos de propiedadclaramente definidos como condición para determinar los pagos por la preservación de servicios ambientales - niega la existencia del conflicto histórico sobre la tierra en Chiapas, y por ello introduce una nueva dimensión al respecto. El presente ensayo advierte que la creciente ubicuidad de las estrategias de conservación basadas en el mercado, como es el CBMM, amenazan con conducir o exacerbar conflictos de tierra y recursos, y tienden a generar resultados que favorecen a actores poderosos locales. En este caso, tales proyectos, más que solucionar la pobreza y la desigualdad, pueden conducir a nuevas formas de marginalización, minando así los objetivos de conservación.

Palabras clave: Fondo para el Medio Ambiente Mundial, Corredor Biológico Mexico-Mesoamericano, los instrumentos de mercado, los conflictos de tenencia de tierras. 